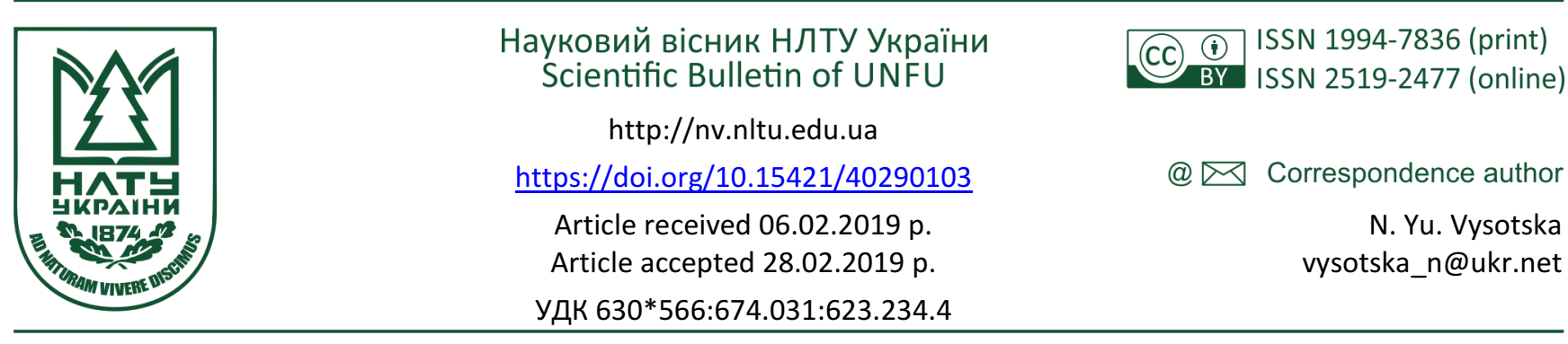

Н. Ю. Висоцька, О. В. Кобець

Украӥнський НДІ лісового господарства і агромеліораиії ім. Г. М. Висоиького, м. Харків, Украйна

\title{
ОСОБЛИВОСТІ РОСТУ ТА ФОРМУВАННЯ ШТУЧНИХ НАСАДЖЕНЬ ТОПОЛІ ЧОРНОÏ (POPULUS NIGRA L.)
}

\begin{abstract}
Для підвищення ефективності ведення лісового господарства в осокоревих (Populus nigra L.) лісах існує потреба розроблення нормативно-інформаційних матеріалів для оцінювання та прогнозування росту насаджень 3 урахуванням зональних особливостей і лісорослинних умов. Побудовано математичні моделі та складено таблиці ходу росту модальних штучних насаджень тополі чорної, які ростуть в умовах свіжого і вологого сугруду в Поліссі, Лісостепу та Степу України, способом комплексного аналізу повидільної бази даних ВО "Укрдержліспроект" та матеріалів пробних площ. Встановлено, що модальні штучні тополеві деревостани в умовах $\mathrm{C}_{2}$ i $\mathrm{C}_{3}$ ростуть за II-III класами бонітету, а їхній запас у 70-річному віці сягає 435, 450 та $500 \mathrm{~m}^{3} \cdot$ га $^{-1}$ в умовах Степу, Лісостепу та Полісся відповідно. Модальні штучні насадження поступаються за запасом культурам тополі чорної вологого сугруду за даними чинних нормативів на 6-37\% та переважають відповідні показники свіжого сугруду на 1-54 \%. Встановлено, що математичні співвідношення доволі точно характеризують хід росту штучних тополевих деревостанів свіжого та вологого сугрудів, а коефіцієнти детермінації рівнянь змінюються в межах 0,90-0,99. Визначено вік кількісної стиглості тополевих насаджень, який незалежно від природної зони в умовах свіжого та вологого сугруду становить 30-35 років.
\end{abstract}

Ключові слова: тополя чорна; математичні моделі; таблиці ходу росту; вік стиглості.

Вступ. Серед представників роду Populus L. деревостани тополі чорної (Populus nigra L.) мають істотне екологічне та господарське значення. В Україні ліси за участю тополі чорної представлені на площі 13,5 тис. га, що становить близько $46 \%$ лісового фонду тополевих деревостанів рівнинної частини України (Vysotska, 2017). Загалом розподіл площ тополевих деревостанів за віком $є$ далеким від оптимального, частка площ деревостанів IX і більше класів віку сягає понад $70 \%$ (Vysotska \& Tkach, 2016).

В Україні дослідження щодо особливостей росту та розвитку осокірників беруть початок із 60 -х років минулого століття (Lavrinenko et al., 1966; Red'ko, 1975). Наразі наявні таблиці ходу росту тополь лише віком до 30-40 років. Загалом більшість таблиць ходу росту (Zagreev, 1978; Kozlovskiy \& Pavlov, 1967; Normativnospravochnyie materialyi, 1987; Lakida et al., 2006; Miklush, 2007; Strochinskiy, 1992) розроблено переважно для нормальних деревостанів. Удосконалення лісотаксаційних нормативів з урахуванням типів лісорослинних умов сприятиме вирішенню актуального завдання як поточної інвентаризації тополевих деревостанів, так і прогнозування динаміки їхнього росту.

Метою роботи є визначення та аналіз особливостей ходу росту і продуктивності штучних насаджень тополі чорної в найпоширеніших типах лісорослинних умов у різних природних зонах рівнинної частини України.
Матеріали і методи дослідження. Для визначення особливостей росту та формування модальних деревостанів та побудови таблиць ходу росту за загальноприйнятими методиками (Anuchin, 1982; Zagreev, 1978; Miklush, 2007; Hrom, 2007) використано повидільну базу даних ВО "Укрдержліспроект" станом на 01.01.2011 p., а також дані пробних площ. Для забезпечення достатньої вибірки для побудови математичних моделей росту проаналізовано 4650 таксаційних виділів осокоревих деревостанів. Закладання пробних площ та оброблення даних здійснювали згідно із загальноприйнятими в лісівництві та лісовій таксації методиками (Anuchin, 1982; Hrom, 2007) і методами математичної статистики (Lapach, Chubenco \& Babych, 2001).

Результати дослідження. Використання бази даних ВО "Укрдержліспроект" у поєднанні з даними пробних площ забезпечують достатню вибірку для побудови математичних моделей росту лісових насаджень (Miklush, 2007; Hrom, 2007). У роботі представлено ескіз таблиць ходу росту, оскільки моделювання частини, що вирубують, $є$ ускладненим через відмінності у веденні господарства в лісах різних категорій та значні площі природних зон.

Обговорення дослідження. Встановлено, що більше половини осокірників (52\%) зосереджені в Степу, $36 \%$ - у Лісостепу та лише $12 \%$ - в Поліссі. У Поліссі та Лісостепу насадження тополі чорної зосереджені на

\section{Інформація про авторів:}

Висоцька Наталя Юріївна, канд. с.-г. наук, ст. наук. співробітник, перший заступник директора з наукових питань. Email: vysotska_n@ukr.net; https://orcid.org/0000-0002-3033-2036

Кобець Олексій Володимирович, канд. с.-г. наук, вчений секретар. Email: alexei_kobec@ukr.net

Цитування за Дсту: Висоцька Н. Ю., Кобець О. В. Особливості росту та формування штучних насаджень тополі чорної (Рориlus Nigra L.). Науковий вісник НлтУ України. 2019, т. 29, № 1. С. 20-23.

Citation APA: Vysotska, Yu N., \& Kobets, O. V. (2019). Features of Growth and Formation Artificial Stands of the Black Poplar (Populus Nigra L.). Scientific Bulletin of UNFU, 29(1), 20-23. https://doi.org/10.15421/40290103 
Лівобережжі (табл. 1). За походженням переважають вить $77 \%$, у Лісостепу - $52 \%$, а в Степу - $42 \%$. штучні насадження, частка площ яких у Поліссі стано-

Табл. 1. Розподіл площі насаджень тополі чорної за походженням

\begin{tabular}{|c|c|c|c|c|c|c|}
\hline \multirow[b]{3}{*}{ Лісогосподарський округ } & \multirow{3}{*}{$\begin{array}{l}\text { Показ- } \\
\text { ник }\end{array}$} & \multicolumn{5}{|c|}{ Походження } \\
\hline & & \multicolumn{3}{|c|}{ природне } & \multirow[b]{2}{*}{$\begin{array}{l}\text { насінне } \\
\text { штучне }\end{array}$} & \multirow[b]{2}{*}{ разом } \\
\hline & & $\begin{array}{c}\text { вегетативне } \\
\text { коренево-па- } \\
\text { росткове }\end{array}$ & $\begin{array}{l}\text { вегетативне } \\
\text { паросткове }\end{array}$ & насінне & & \\
\hline \multirow{2}{*}{ Східне (Києво-Чернігівське) Полісся } & га & 7,7 & 73,3 & 279,0 & 1196,6 & 1556,6 \\
\hline & $\%$ & 0,5 & 4,7 & 17,9 & 76,9 & 100 \\
\hline \multirow[t]{2}{*}{ Західне та Центральне Полісся } & га & - & 8,0 & 0,3 & 63,3 & 71,6 \\
\hline & $\%$ & - & 11,2 & 0,4 & 88,4 & 100 \\
\hline \multirow{2}{*}{ Полісся - разом } & га & 7,7 & 81,3 & 279,3 & 1259,9 & 1628,2 \\
\hline & $\%$ & 0,5 & 5 & 17,1 & $\mathbf{7 7 , 4}$ & 100 \\
\hline \multirow[t]{2}{*}{ Західноукраїнський лісостеповий } & га & - & 10,4 & 3,9 & 37,4 & 51,7 \\
\hline & $\%$ & $\begin{array}{llll}- & & & \\
\end{array}$ & 20,1 & 7,5 & 72,4 & 100 \\
\hline \multirow[t]{2}{*}{ Дністровсько-Дніпровський лісостеповий } & га & 5,0 & 167,9 & 12,2 & 274,9 & 460,0 \\
\hline & $\%$ & 1,1 & 36,4 & 2,7 & 59,8 & 100 \\
\hline \multirow[t]{2}{*}{ Лівобережно-Дніпровський лісостеповий } & га & 1,8 & 1271,1 & 806,6 & 1776,2 & 3855,7 \\
\hline & $\%$ & - & 33 & 20,9 & 46,1 & 100 \\
\hline \multirow{2}{*}{ Середньоруський лісостеповий } & га & - & 48,7 & 5,3 & 473,0 & 527,0 \\
\hline & $\%$ & - & 9,2 & 1,0 & 89,8 & 100 \\
\hline \multirow[t]{2}{*}{ Лісостеп - разом } & га & 6,8 & 1498,1 & $\mathbf{8 2 8 , 0}$ & 2561,5 & 4894,4 \\
\hline & $\%$ & $\mathbf{0 , 1}$ & 30,6 & 16,9 & 52,4 & 100 \\
\hline \multirow{2}{*}{$\begin{array}{l}\text { Правобережно-Дніпровський північно-степо- } \\
\text { вий }\end{array}$} & га & - & 28,2 & 555,3 & 313,5 & 897,0 \\
\hline & $\%$ & - & 3,1 & 61,9 & 35,0 & 100 \\
\hline \multirow[t]{2}{*}{ Лівобережно-Дніпровський північно-степовий } & га & 7,4 & 1018,7 & 559,1 & 1653,3 & 3238,5 \\
\hline & $\%$ & 0,2 & 31,5 & 17,3 & 51,0 & 100 \\
\hline \multirow[t]{2}{*}{ Донецько-Донський північно-степовий } & га & 1,4 & 1317,5 & 210,1 & 391,0 & 1920,0 \\
\hline & $\%$ & 0,1 & 68,6 & 10,9 & 20,4 & 100 \\
\hline \multirow{2}{*}{$\begin{array}{l}\text { Причорноморсько-Приазовський південно-сте- } \\
\text { повий }\end{array}$} & га & - & 271,2 & 44,7 & 495,7 & 811,6 \\
\hline & $\%$ & - & 33,4 & 5,5 & 61,1 & 100 \\
\hline \multirow[t]{2}{*}{ Степ - разом } & га & 8,8 & 2635,6 & 1369,2 & 2853,5 & 6867,1 \\
\hline & $\%$ & $\mathbf{0 , 1}$ & 38,4 & 19,9 & 41,6 & 100 \\
\hline
\end{tabular}

Більшість насаджень тополі чорної росте в умовах свіжих та вологих сугрудів. Частка площ лісів у цих умовах у Поліссі становить $77 \%$, у Лісостепу - $67 \%$, у Степу - 33 \% Частка площ порівняно високопродуктивних штучних насаджень II-III класів бонітету свіжого сугруду у Поліссі становить $67 \%$, у Лісостепу - $47 \%$, у Степу - 29 \%. В умовах вологого сугруду частка площ культур II-III класів бонітету відповідно становить $65 \%, 69 \%$ та $42 \%$ (табл. 2).

Табл. 2. Розподіл площі штучних насаджень тополі чорної свіжого то вологого сугруду за класами бонітету в розрізі природних зон

\begin{tabular}{|c|c|c|c|c|c|c|}
\hline \multirow{3}{*}{$\begin{array}{c}\text { Клас } \\
\text { бонітету }\end{array}$} & \multicolumn{6}{|c|}{ Природна зона } \\
\hline & \multicolumn{2}{|c|}{ Полісся } & \multicolumn{2}{|c|}{ Лісостеп } & \multicolumn{2}{|c|}{ Степ } \\
\hline & га & $\%$ & га & $\%$ & га & $\%$ \\
\hline \multicolumn{7}{|c|}{ Свіжий сугруд $\left(\mathrm{C}_{2}\right)$} \\
\hline Ia & 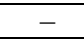 & - & 1,1 & 0,2 & - & - \\
\hline $\mathrm{I}$ & 0,4 & 1,2 & 0,6 & 0,1 & - & - \\
\hline II & 16,6 & 51,1 & 37,6 & 6,2 & 17,8 & 3,3 \\
\hline III & 5,3 & 16,3 & 246,7 & 40,6 & 142 & 26,0 \\
\hline IV & 1,3 & 4,0 & 277,1 & 45,5 & 252,1 & 46,1 \\
\hline $\mathrm{V}$ & 8,9 & 27,4 & 45,2 & 7,4 & 126,9 & 23,2 \\
\hline $\mathrm{Va}$ & - & - & - & - & 7,8 & 1,4 \\
\hline Разом & 32,5 & 100,0 & 608,3 & 100,0 & 546,6 & 100,0 \\
\hline \multicolumn{7}{|c|}{ Вологий сугруд $\left(\mathrm{C}_{3}\right)$} \\
\hline Ia & 11,9 & 1,3 & 4,5 & 0,4 & - & - \\
\hline $\mathrm{I}$ & 52,1 & 5,5 & 33,0 & 2,9 & - & - \\
\hline II & 185,8 & 19,6 & 247,8 & 21,7 & 23,7 & 6,3 \\
\hline III & 430,5 & 45,5 & 543,7 & 47,6 & 134,8 & 35,5 \\
\hline IV & 210,9 & 22,3 & 292,8 & 25,6 & 154 & 40,6 \\
\hline $\mathrm{V}$ & 53,1 & 5,6 & 21,2 & 1,8 & 66,7 & 17,6 \\
\hline $\mathrm{Va}$ & 2,3 & 0,2 & - & 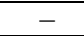 & - & - \\
\hline Разом & 946,6 & 100,0 & 1143,0 & 100,0 & 379,2 & 100,0 \\
\hline
\end{tabular}

Для порівняльного аналізу продуктивності тополевих насаджень у різних природних зонах побудовано таблиці ходу росту штучних насаджень свіжого та вологого сугруду II-III класів бонітету Східного Полісся,
Лівобережного Лісостепу та Степу. Для розроблення математичних моделей росту модальних деревостанів важливим є визначення кореляційного зв'язку між їхніми середньозваженими таксаційними показниками. Напрямок і тісноту зв'язків між таксаційними показниками модальних деревостанів встановлювали за величинами коефіцієнтів кореляції (табл. 3), які допомагають визначитися у підборі аргументів під час розроблення регресійних моделей (Kozlovskiy \& Pavlov, 1967; Lapach et al., 2001).

Табл. 3. Кореляційна матриця таксаційних показників штучних тополевих деревостанів свіжого та вологого сугруду

\begin{tabular}{|c|c|c|c|c|c|c|}
\hline $\begin{array}{c}\text { Такса- } \\
\text { ційний } \\
\text { показник }\end{array}$ & $A$, років & $H, \mathrm{~m}$ & $D, \mathrm{~cm}$ & $N$, шт. & $\begin{array}{c}G, \\
\mathrm{~m}^{2} \cdot \mathrm{ra}^{-1}\end{array}$ & $\begin{array}{c}M, \\
\mathrm{M}^{3} \cdot \mathrm{ra}^{-1}\end{array}$ \\
\hline \multicolumn{7}{|c|}{ Східне Полісся } \\
\hline$A$, років & $\mathbf{1}$ & 0,972 & 0,995 & $-0,746$ & 0,866 & $\overline{0,974}$ \\
\hline$H, \mathrm{M}$ & 0,972 & 1 & 0,989 & 0,853 & 52 & 0,998 \\
\hline$D, \mathrm{~cm}$ & 5 & 989 & 1 &, 782 & 900 & 992 \\
\hline$N$, шт. & $-0,746$ & $-0,853$ & $-0,782$ & 1 & 0,961 & 0,830 \\
\hline$G, \mathrm{M}^{2}$ & 866 & 0,952 & & $-0,961$ & 1 & 0,941 \\
\hline$M, \mathrm{M}^{3} \cdot \mathrm{га}^{-1}$ & 0,974 & 0,998 & 0,992 & $-0,830$ & 0,941 & 1 \\
\hline \multicolumn{7}{|c|}{ Лівобережний Лісостеп } \\
\hline$A$, років & 1 & 0,962 & 0,991 & $-0,741$ & 0,878 & 0,973 \\
\hline$H, \mathrm{~m}$ & ,962 & 1 & 988 & & & 0,998 \\
\hline$D, \mathrm{c}$ & & 988 & 1 & 0,792 & 21 & 995 \\
\hline$N$, ш & 741 & $-0,862$ &, 792 & & 0,961 & $-0,831$ \\
\hline$G, \mathrm{M}^{2}$ & & 0,965 & 0,921 & & 1 & 0,948 \\
\hline$M, \mathrm{M}^{3} \cdot \mathrm{\Gamma a}^{-1}$ & 0,973 & 0,998 & 0,995 & $-0,831$ & 0,948 & 1 \\
\hline \multicolumn{7}{|c|}{ Степ } \\
\hline$A$, років & & 0,960 & 0,977 & $-0,738$ & 0,893 & 0,975 \\
\hline$H, \mathrm{M}$ & 0,960 & 1 & 0,996 & $-0,863$ & 0,974 & 0,997 \\
\hline$D, \mathrm{~cm}$ & & 0,996 & 1 & $-0,821$ & 0,952 & 0,999 \\
\hline$N$, шт. & & &, 821 & & $-0,951$ & $-0,825$ \\
\hline$G, \mathrm{M}^{2}$ & & 0,974 & 0,952 & $-0,951$ & 1 & 0,956 \\
\hline $\bar{M}, \mathrm{M}^{3} \cdot \mathrm{ra}^{-1}$ & 0,975 & 0,997 & 0,999 & $-0,825$ & 0,956 & \\
\hline
\end{tabular}


Вік $(A)$, висота $(H)$, діаметр $(D)$, сума площ перерізів на 1 га $(G)$, запас на 1 га $(M)$ характеризуються прямо пропорційними тісними зв'язками, кількість дерев на 1 га $(N)$ відрізняється обернено пропорційним зв'язком відносно до інших показників.

Важливим показником для встановлення ходу росту $\epsilon$ середня висота деревостану, оскільки з нею пов'язані решта параметрів; вона має меншу варіацію, порівняно iз середнім діаметром, кількістю стовбурів, сумою площ перерізу чи запасом. Для апроксимації середньої висоти модальних осокорових деревостанів підібрано функції (1-3):

$$
\begin{gathered}
H_{\text {Полісся }}=-0,00573 \times \mathrm{A}^{2}+0,851 \times \mathrm{A}+0,641, R^{2}=0,98 \\
H_{\text {Лiсостеп }}=-0,0065 \times \mathrm{A}^{2}+0,895 \times \mathrm{A}+0,169, R^{2}=0,99 \\
H_{\text {Cтеп }}=-0,0064 \times \mathrm{A}^{2}+0,874 \times \mathrm{A}+0,140, R^{2}=0,99
\end{gathered}
$$

На величину середнього діаметра найбільше впливають вік і висота деревостану, тому для моделювання середнього діаметра використовували відношення діаметра до висоти (D/H), яке апроксимують функціями (4-6):

$$
\begin{aligned}
& \frac{D}{H}_{\text {Полісся }}=-0,0057 \times A^{2}+0,851 \times A+0,641, R^{2}=0,99 ; \\
& \frac{D}{H}{ }_{\text {Лісостеп }}=-0,0065 \times A^{2}+0,895 \times A+0,169, R^{2}=0,96 ; \\
& \frac{D}{H}_{\text {Степ }}=-0,000123 \times A^{2}+0,0167 \times A+0,899, R^{2}=0,93 .
\end{aligned}
$$

Одним з основних таксаційних показників деревостану є сума площ перерізів стовбурів $(\mathrm{G})$, яку прийнято згідно з нормативно-довідковими матеріалами для тополевих насаджень (Kashpor \& Strochinskiy, 2013), вона апроксимують функцією (7):

$$
G=-0,0408 \times \mathrm{A}^{2}+3,385 \times \mathrm{A}-4,271, R^{2}=0,99
$$

Фактичну суму площ перерізів визначали через відносну повноту. Динаміку відносної повноти штучних насаджень тополі чорної добре описують поліноми другого порядку (8-10):

$$
\begin{aligned}
& P_{\text {Полісся }}=0,000055 \cdot A^{2}-0,00726 \cdot A+0,808, R^{2}=0,98 ; \\
& P_{\text {Лісостеп }}=0,000097 \cdot A^{2}-0,00996 \cdot A+0,793, R^{2}=0,90 ; \\
& P_{\text {Степ }}=0,000077 \cdot A^{2}-0,00801 \cdot A+0,736, R^{2}=0,98
\end{aligned}
$$

Моделювання динаміки видових чисел проводили 3 використанням видової висоти (HF). Залежність видових висот від віку описують поліноміальними функціями другого порядку (11-13):

$$
\begin{gathered}
H F_{\text {Полісся }}=-0,00247 \times \mathrm{A}^{2}+0,364 \times \mathrm{A}+0,828, R^{2}=0,98 ;(11) \\
H F_{\text {Лiсотеп }}=-0,00280 \times \mathrm{A}^{2}+0,383 \times \mathrm{A}+0,662, R^{2}=0,99 ;(12) \\
H F_{\text {Cтеп }}=-0,00274 \times \mathrm{A}^{2}+0,372 \times \mathrm{A}+0,684, R^{2}=0,99 .(13)
\end{gathered}
$$

Решту параметрів для деревостанів основної частини визначали за відомими формулами лісової таксації (Anuchin, 1982). Коефіцієнти детермінації $(0,90-0,99)$ свідчать про високий рівень достовірності, їх використали для формування таблиць ходу росту модальних деревостанів (табл. 4). Таблиці ходу росту модальних деревостанів варто використовувати під час планування обсягів проміжного користування, зокрема рубань догляду.

Модальні штучні насадження поступаються за запасом культурам тополі чорної вологого сугруду за даними Г. I. Редька (Red'ko, 1975) на 6-37 \% та переважають відповідні показники свіжого сугруду на 1-4\%. До найважливіших елементів у системі ведення лісового

\begin{tabular}{|c|c|c|c|c|c|c|c|c|}
\hline \multirow{3}{*}{$\begin{array}{c}A, \\
\text { років }\end{array}$} & \multicolumn{8}{|c|}{ Деревостан } \\
\hline & \multirow{2}{*}{$H, \mathrm{~m}$} & \multirow{2}{*}{$D, \mathrm{~cm}$} & \multirow{2}{*}{$N$, шт. } & \multirow{2}{*}{$\begin{array}{c}G, \\
\mathrm{м}^{2} \mathrm{ra}^{-1}\end{array}$} & \multirow{2}{*}{ 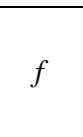 } & \multirow{2}{*}{$\begin{array}{c}M, \\
\mathrm{~m}^{3} \text { га }^{-1}\end{array}$} & \multicolumn{2}{|c|}{$\begin{array}{c}\Delta M, \mathrm{~m}^{3} \\
\Gamma \mathrm{ra}^{-1} \cdot \mathrm{pi \kappa}^{-1}\end{array}$} \\
\hline & & & & & & & cep. & $\begin{array}{c}\text { По- } \\
\text { точн. }\end{array}$ \\
\hline \multicolumn{9}{|c|}{ Східне Полісся } \\
\hline 10 & 8,6 & 9,1 & 2477 & 16,1 & 0,491 & 68 & 6,8 & 9,2 \\
\hline 20 & 15,4 & 18,5 & 967 & 26,0 & 0,462 & 185 & 9,3 & 12,0 \\
\hline 30 & 21,0 & 28,0 & 506 & 31,2 & 0,454 & 297 & 9,9 & 10,8 \\
\hline 40 & 25,5 & 37,0 & 315 & 33,9 & 0,448 & 387 & 9,7 & 8,6 \\
\hline 50 & 28,9 & 45,1 & 216 & 34,5 & 0,445 & 444 & 8,9 & 6,0 \\
\hline 60 & 31,1 & 51,5 & 169 & 35,1 & 0,443 & 484 & 8,1 & 2,8 \\
\hline 70 & 32,1 & 55,8 & 146 & 35,6 & 0,443 & 506 & 7,2 & 1,8 \\
\hline \multicolumn{9}{|c|}{ Лівобережний Лісостеп } \\
\hline 10 & 8,5 & 9,0 & 2359 & 15,1 & 0,496 & 64 & 6,4 & 9,0 \\
\hline 20 & 15,5 & 18,5 & 900 & 24,2 & 0,465 & 174 & 8,7 & 11,0 \\
\hline 30 & 21,2 & 27,9 & 466 & 28,5 & 0,454 & 274 & 9,1 & 9,6 \\
\hline 40 & 25,6 & 36,5 & 293 & 30,6 & 0,449 & 352 & 8,8 & 7,4 \\
\hline 50 & 28,7 & 43,8 & 212 & 32,0 & 0,447 & 411 & 8,2 & 5,8 \\
\hline 60 & 30,5 & 49,3 & 172 & 32,9 & 0,445 & 447 & 7,5 & 3,0 \\
\hline 70 & 31,0 & 52,5 & 153 & 33,2 & 0,444 & 457 & 6,5 & 0,4 \\
\hline \multicolumn{9}{|c|}{ Степ } \\
\hline 10 & 8,2 & 8,6 & 2362 & 13,7 & 0,504 & 57 & 5,7 & 8,0 \\
\hline 20 & 15,1 & 17,9 & 909 & 22,9 & 0,465 & 161 & 8,1 & 10,8 \\
\hline 30 & 20,6 & 26,6 & 495 & 27,5 & 0,455 & 258 & 8,6 & 9,8 \\
\hline 40 & 24,9 & 34,2 & 321 & 29,5 & 0,449 & 330 & 8,3 & 7,0 \\
\hline 50 & 27,8 & 39,9 & 247 & 30,9 & 0,447 & 384 & 7,7 & 5,4 \\
\hline 60 & 29,5 & 43,3 & 217 & 31,9 & 0,445 & 419 & 7,0 & 2,6 \\
\hline 70 & 30,0 & 44,4 & 211 & 32,7 & 0,444 & 435 & 6,2 & 0,4 \\
\hline
\end{tabular}
господарства належать віки стиглості, які залежать від породного складу, умов місцезростання, походження, бонітету, режиму господарювання, особливостей структури лісового фонду (Tkach, Pasternak \& Buksha, 2002). Вік кількісної стиглості модальних штучних деревостанів тополі чорної, який визначено за зміною запасу, $є$ однаковим у трьох природних зонах - у Східному Поліссі, Лівобережному Лісостепу та Степу - і становить 34 роки (рисунок).

Табл. 4. Ескіз таблиць ходу росту модальних штучних деревостанів тополі чорної свіжого та вологого сугрудів II-III класів бонітету

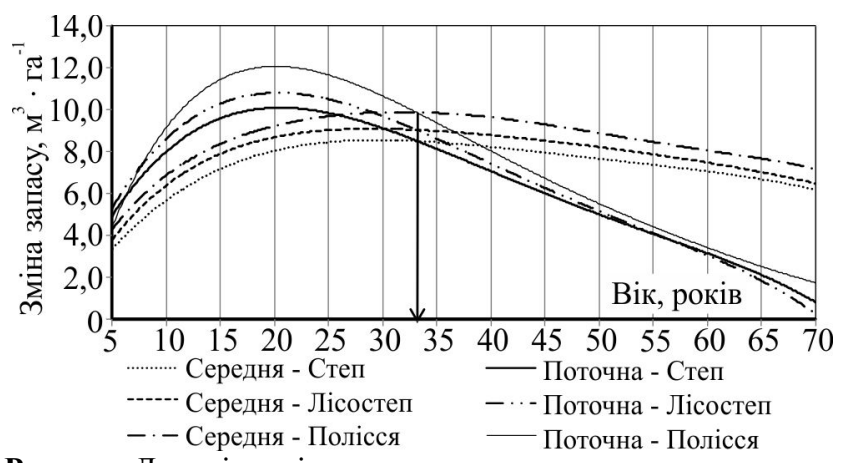

Рисунок. Динаміка зміни запасу модальних штучних деревостанів тополі чорної свіжого та вологого сугрудів

Отримані результати надалі доцільно враховувати під час обгрунтування і уточнення віків стиглості тополевих деревостанів з огляду на їхнє походження, продуктивність та лісорослинні умови.

Висновки. Насадження тополі чорної переважно зосереджені у Степу та Лісостепу та представлені культурами II-III класів бонітету, що ростуть в умовах свіжого та вологого сугруду. У Поліссі та Лісостепу насадження тополі чорної зосереджені переважно на Лівобережній частині України, а в Степу - як у північний, так і в південній його частинах. Розроблені таблиці ходу росту об'єктивно характеризують особливості росту і формування модальних штучних тополевих деревостанів рівнинної частини України, їх доцільно використовувати для планування обсягів проміжного користування. Вік кількісної стиглості штучних тополевих насаджень, 
визначений за зміною запасу, припадає на сьомий клас віку та становить $30-35$ років.

\section{Перелік використаних джерел}

Anuchin, N. P. (1982). Lesnaia taksatciia. Moscow: Lesnaia promyshlennost, 552 p. [In Russian].

Guoqing, W., Kun, C., Wenkang, H., et al. (1992). On yield table and its general research condition in China. Journal of Northeast Forestry University, 3(2), 70-77. https://doi.org/10.1007/BF02843040

Hrom, M. M. (2007). Lisova taksatsiia. (2nd ed.). Lviv, 409 p. [In Ukrainian].

Kashpor, S. M., \& Strochynskyi, A. A. (2013). Lisotaksatsiinyi dovidnyk. Kyiv: Vinichenko, 496 p. [In Ukrainian].

Kozlovskii, V. B., \& Pavlov, V. M. (1967). Khod rosta lesoobrazuiushhikh porod SSSR. Moscow: Lesn. prom-st, 327 p. [In Russian].

Lakyda, P. I., Lashchenko, A. H., \& Lashchenko, M. M. (2006). Biolohichna produktyvnist dubovykh derevostaniv Podillia. Kyiv: NNTs IAE, 196 p. [In Ukrainian].

Lapach, S. N., Chubenko, A. V., \& Babich, P. N. (2001). Statisticheskie metody v mediko-biologicheskikh issledovaniiakh s ispolzovaniem Excel. Kyiv: MORION, 408 p. [In Russian].

Lavrinenko, D. D., Redko, G. I., Lishenko, A. A., et al. (1966). Sozdanie topolevykh nasazhdenii. Moscow, 315 p. [In Russian].

Longchang, L., Wenkang, H., \& Guoqing, W. (1991). Study on the method of constructing variable-density yield table. Journal of
Northeast Forestry University, 2(2), 95-99. https://doi.org/10.1007/BF02874814

Myklush, S. I. (2006). Modeliuvannia rostu u vysotu rivnynnykh bukovykh derevostaniv. Forestry, Forest, Paper and Woodworking Industry, 31, 203-211. [In Ukrainian].

Redko, G. I. (1975). Biologiia i kultura topolei. Leningrad, 175 p. [In Russian].

Shvydenko, A. Z., Strochinskii, A. A., Savich, IU. N., \& Kashpor, S. N. (Eds). (1987). Normativno-spravochnye materialy dlia taksatcii lesov Ukrainy i Moldavii. Kyiv: Urozhai, 560 p. [In Russian].

Strochinskii, A. A. (1992). Metodicheskoe i normativno-informatcionnoe obespechenie sistemy regulirovaniia produktivnosti lesnykh nasazhdenii na Ukraine. Abstract of Doctoral Dissertation for Agricultural Sciences (06.03.02 - Forest Management and Forest Taxation). Kyiv, 70 p. [In Russian].

Tkach, V. P., Rohovyi, V. I., \& Pasternak, V. P. (2009). Modeliuvannia khodu rostu bukovykh derevostaniv Krymu. Forestry and Agroforestry, 115, 80-89. [In Ukrainian].

Vysotska, N. Yu. (2017). Suchasnyi stan i perspektyvy zberezhennia henetychnykh resursiv topoli v Ukraini. Proceedings of the Forestry Academy of Sciences of Ukrain, 15, 38-44. [In Ukrainian].

Vysotska, N. Yu., \& Tkach, V. P. (2016). Derevostany topoli ta osyky v Ukraini. Forestry and Agroforestry, 128, 136-137. [In Ukrainian].

Zagreev, V. V. (1978). Geograficheskie zakonomernosti rosta i produktivnosti drevostoev. Moscow: Lesn. prom-st, 237 p. [In Russian].

\section{Ukrainian Research Institute Forestry And Agromelioration named after H. M. Vysotskiy, Kharkiv, Ukraine \\ FEATURES OF GROWTH AND FORMATION ARTIFICIAL STANDS OF THE BLACK POPLAR (POPULUS NIGRA L.)}

The black poplar stands (Populus nigra L.) provide a range of ecological services and have an economic significance. Stands of IX and higher age classes are dominating. Therefore, it is necessary to systematize data on the productivity of black poplar in various natural and climatic zones of Ukraine. Yield tables are the basis for regulatory and reference data in forest management, accounting of forests and forest resources. Most of existing yield tables was developed primarily for normal stands. Such tables do not take into account regional characteristics of growth and state of forest plantations. The aim of the investigation is to determine the characteristics of the course of growth and productivity artificial modal black poplar stands in various natural and climatic zones of Ukraine. To determine the characteristics of growth and formation of modal stands and to develop yield tables, data of Forest inventory Database of Production Association "Ukrderzhlisproekt" were analyzed using conventional techniques. Yield tables for Populus nigra L. were constructed from 4650 plots.

A significant differentiation in the dynamics of areas and stocks of poplar stands has been found by age classes in different natural and climatic zones and typological range. It was established that modal artificial stands black poplar grows in II-III site class in the conditions of mesic mesotrophic $\left(\mathrm{C}_{2}\right)$ and meso-hygric mesotrophic $\left(\mathrm{C}_{3}\right)$ (in accordance with the Alekseev-Pogrebnyak edaphic grid). Forest yield at the age of 70 is reaching 435,450 and $500 \mathrm{~m}^{3} \mathrm{ha}^{-1}$ in the conditions of Steppe, Forest-Steppe and Polissya, respectively. The mathematical relationships accurately characterize the growth of artificial black poplar stands of conditions of mesic mesotrophic and meso-hygric mesotrophic, and the determination coefficients of the equations fluctuate between 0.90-0.99. By the ratio of mean and current annual increments in yield tables the age (30-35) of quantitative maturity of modal stands was identified.

Keywords: black poplar; mathematical models; yield tables; maturity age. 